\title{
PERHITUNGAN LENDUTAN PONDASI TELAPAK DENGAN METODE ELEMEN HINGGA
}

\author{
Hanny J. Dani ${ }^{[1]}$, Olga Pattipawaej ${ }^{[2]}$, Putra W. Remantan ${ }^{[3]}$
}

\begin{abstract}
Civil engineering structures such as building, road and bridge congregate at the ground. Frequently, the ground doesn't fulfill the strength criterion of the bearing capacity to support the structural loads, so that it is required resolving that problem. The foundation bear load which in transmitted by column before distribute to the ground. One of parameter that needs to be paid attention in a foundation design is a displacement. In this article, spread foundation displacement is determined using finite element method. The spread foundation is assumed as a rigid structure and is located at the joint of elastic spring in the place of modulus influence reaction of the soil. The design of the plate foundation is modelled as a stiffness matrix equation of the modified thin plate for the soil. A case study is performed to obtain the displacement at each nodal point. In finite element method, spread foundation is modeled as an elastic plate. The maximum displacement is obtained and the comparison is made by analytical and numerical calculation using software SAP2000. The difference result of maximum displacement using analytical and numerical computation is $0.28 \%$.
\end{abstract}

Keywords: spread foundation, displacement, finite element method.

\begin{abstract}
ABSTRAK
Bangunan teknik sipil seperti gedung, jalan dan jembatan bertumpu pada lapisan tanah. Dalam pelaksanaan pembangunan sering kali tanah tersebut tidak memenuhi kriteria kekuatan untuk memikul beban dari struktur di atasnya, sehingga diperlukan suatu pemecahan dalam masalah tersebut. Pondasi memikul beban yang di salurkan oleh kolom sebelum diteruskan ke tanah. Salah satu parameter yang perlu diperhatikan dalam suatu desain pondasi adalah lendutan. Dalam tulisan ini, lendutan pondasi telapak dihitung dengan menggunakan metode elemen hingga. Pondasi diasumsikan sebagai struktur yang rigid dan berada di atas tumpuan elastis/pegas sebagai pengganti pengaruh modulus reaksi tanah. Desain pondasi pelat dimodelkan sebagai persamaan matrik dari perilaku pelat tipis yang dimodifikasi terletak di atas tanah. Studi kasus dilakukan untuk mendapatkan lendutan pada tiap-tiap titik nodal. Dalam metode elemen hingga, pondasi telapak dimodelkan sebagai pelat lentur. Hasil lendutan maksimum dengan perhitungan manual dan numerik dengan menggunakan software SAP2000. Perbedaan hasil lendutan maksimum dari kedua metode ini diperoleh sebesar $0.28 \%$.
\end{abstract}

Kata kunci: pondasi telapak, lendutan, metode elemen hingga.

\section{PENDAHULUAN}

Geoteknik merupakan suatu bagian dari ilmu Teknik Sipil. Didalamnya diperdalam pembahasan mengenai permasalahan kekuatan tanah dan hubungannya dengan kemampuan menahan beban bangunan yang berdiri diatasnya. Pada dasarnya ilmu ini tergolong ilmu tua yang berjalan bersamaan dengan tingkat peradaban manusia, dari mulai pembangunan Piramid di Mesir, candi Borobudur hingga pembangunan gedung pencakar langit sekarang ini. Salah satu contohnya ialah kemiringan menara Pisa di Itali disebabkan kurangnya 
kekuatan dukung tanah terhadap menara tersebut. Secara keilmuan, bidang Teknik Sipil ini mempelajari lebih mendalam ilmu ilmu seperti mekanika tanah dan batuan, teknik pondasi (suatu upaya teknis untuk mendapatkan jenis dan dimensi pondsi bangunan yang efisien, sehingga dapat menyangga beban yang bekerja dengan baik) dan struktur bawah tanah.

Semua konstruksi yang direkayasa untuk bertumpu pada tanah harus didukung oleh suatu pondasi. Pondasi merupakan bagian dari suatu sistem rekayasa yang meneruskan beban yang ditopang oleh pondasi dan beratnya sendiri kepada dan ke dalam tanah dan batuan yang terletak di bawahnya. Jenis pondasi yang digunakan dalam suatu perencanaan bangunan tergantung dari jenis tanah dan beban yang bekerja pada lokasi rencana proyek. Dalam tulisan ini, pondasi telapak dipilih umumnya dibangun di atas tanah pendukung pondasi dengan membuat suatu tumpuan yang bentuk dan ukurannya (dimensi) sesuai dengan beban bangunan dan daya dukung tanah. Pondasi tersebut bersatu dengan bagian bangunan utama (tembok penahan tanah) sehingga merupakan suatu konstruksi yang monolit.

Beban yang bekerja pada suatu pondasi dapat diproyeksikan menjadi:

1. Beban Horizontal/Beban Geser, contohnya beban akibat gaya tekan tanah, transfer beban akibat gaya angin pada dinding.

2. Beban Vertikal/Beban Tekan dan Beban Tarik, contohnya:
a. Beban Mati, contoh berat sendiri bangunan.
b. Beban Hidup, contoh beban penghuni, air hujan dan salju.
c. Gaya Gempa.
d. Gaya Angkat Air (Lifting Force).

3. Momen.

4. Torsi.

Tegangan-tegangan tanah yang dihasilkan, kecuali pada permukaan tanah, merupakan tambahan kepada beban-beban yang sudah ada dalam massa tanah dari bobot sendiri, bahan dan sejarah geologisnya.

Dalam pelaksanaan pembangunan suatu struktur sering kali tanah tersebut tidak memenuhi kriteria kekuatan untuk memikul beban dari struktur diatasnya. Oleh karena itu, diperlukan suatu pemecahan masalah supaya tanah tersebut dapat memenuhi beban yang dipikul akibat struktur diatasnya. Dalam hal ini, pondasi menerima beban dari kolom sebelum di salurkan ke tanah dan perhitungan lendutan merupakan salah satu parameter yang menjadi pertimbangan dalam desain pondasi. 
Tulisan ini bertujuan untuk mencari pemodelan pondasi telapak dengan memanfaatkan metode elemen hingga dalam menghitung matriks kekakuan elemen, matriks gaya simpul yang kemudian digeneralisasikan menjadi matriks gaya global, menghitung perpindahan nodal dengan memasukan kondisi batas, sehingga menghasilkan lendutan dengan memperhitungkan konstanta pegas sebagai model kondisi tanah.

Dalam penelitian ini, pondasi dimodelkan sebagai pelat dengan ketebalan yang sama di atas konstanta pegas yang terjadi pada lapisan bawah pondasi telapak. Pelat pondasi dianggap sebagai suatu struktur yang terletak di atas tumpuan elastis. Dalam metode elemen hingga pondasi telapak dimodelkan sebagai elemen segiempat dengan menggunakan SAP2000 versi 11. Lendutan pada pelat pondasi akibat beban dan pengaruh modulus reaksi tanah yang dimodelkan sebagai pegas dan dianggap sebagai perletakan yang terjadi di bawah pelat pondasi.

\section{PONDASI}

Untuk memilih pondasi yang memadai, perlu diperhatikan apakah pondasi tersebut cocok untuk berbagai keadaan di lapangan dan apakah pondasi itu memungkinkan untuk diselesaikan secara ekonomis sesuai dengan jadwal pengerjaannya. Bila keadaan tersebut ikut dipertimbangkan dalam menentukan macam pondasi, hal-hal berikut ini perlu dipertimbangkan:

1. Keadaan tanah pondasi

2. Batasan-batasan akibat konstruksi diatasnya (superstructure)

3. Batasan-batasan dari lingkungan sekelilingnya

4. Waktu dan biaya pekerjaan.

Dari ke empat hal di atas, keadaan tanah pondasi merupakan keadaan yang paling penting. Lima jenis pondasi berdasarkan keadaan tanah dijabarkan sebagai berikut (Sosrodarsono dan Nakazawa, 1984):

1. Pondasi telapak (spread foundation)

Bila tanah pendukung pondasi terletak pada permukaan tanah atau terletak 2 sampai 3 meter di bawah permukaan tanah.

2. Pondasi tiang atau pondasi tiang apung (floating pile foundation)

Bila tanah pendukung pondasi terletak pada kedalaman sekitar 10 meter di bawah permukaan tanah. Pondasi ini digunakan untuk memperbaiki tanah pondasi. Jika menggunakan tiang, maka tiang baja atau tiang beton yang dicor di tempat (cast in place) kurang ekonomis karena tiang-tiang tersebut kurang panjang. 


\section{Pondasi tiang pancang (pile driven foundation)}

Bila tanah pendukung pondasi terletak pada kedalaman sekitar 20 meter di bawah permukaan tanah. Dalam hal ini, tergantung dari penurunan (settlement) yang diijinkan. Apabila tidak boleh terjadi penurunan, biasanya digunakan pondasi tiang pancang (pile driven foundation). Tetapi bila terdapat batu besar (cobble stone) pada lapisan antara, pemakaian kaison lebih menguntungkan.

4. Kaison terbuka dan/atau Kaison Tekanan

Bila tanah pendukung pondasi terletak pada kedalaman sekitar 30 meter dibawah permukaan tanah. Dalam hal ini biasanya dipakai kaison terbuka, tiang baja atau tiang yang dicor di tempat. Tetapi bila tekanan atmosfir yang bekerja ternyata kurang dari 3 $\mathrm{kg} / \mathrm{cm}^{2}$ digunakan juga kaison tekanan.

5. Tiang Baja dan Tiang Beton yang dicor di tempat

Bila tanah pendukung pondasi terletak pada kedalaman lebih dari 40 meter di bawah permukaan tanah. Dalam hal ini,yang paling baik dipakai adalah tiang baja dan tiang beton yang dicor di tempat.

Batasan-batasan akibat konstruksi juga penting. Kondisi beban (besar, penyebaran, arah dan lain-lain), sifat dinamis bangunan atas (statis tertentu atau statis tak tertentu, kekakuan dan sebagainya), kegunaan dan kepentingan bangunan atas, kesulitan pemeliharaan dan bahan-bahan untuk bangunan harus diamati. Jenis pondasi yang akan dipakai tergantung kepada sifat bangunan itu mengizinkan untuk tidak terjadinya penurunan pondasi. Apabila jenis struktur bangunan di atasnya telah ditetapkan, maka sulit sekali memilih pondasi yang ekonomis. Suatu jembatan misalnya direncanakan sebagai balok menerus dan jika penurunan pondasi tidak boleh terjadi, seringkali biaya pembuatan pondasi menjadi amat tinggi dan sangat tergantung pada jenis pondasi. Sebaliknya, bila bangunan atas dianggap sebagai balok sederhana dan penurunan diijinkan pada pondasi, maka biaya pengerjaan bangunan atas meningkat, walaupun biaya pengerjaan pondasi menjadi lebih kecil. Secara keseluruhan, jembatan menjadi lebih ekonomis. Berdasarkan segi pelaksanaan, ada beberapa keadaan dimana kondisi lingkungan tidak memungkinkan adanya pekerjaan yang baik sesuai dengan kondisi yang diasumsikan dalam perencanaan.

Jenis pondasi yang akan digunakan pada tulisan ini adalah pondasi telapak (spread foundation). Pondasi telapak adalah suatu pondasi yang mendukung bangunan secara langsung pada tanah pondasi, bila mana terdapat lapisan tanah yang cukup tebal dengan kualitas yang baik yang mampu mendukung bangunan itu pada permukaan tanah atau sedikit di bawah permukaan tanah (Sosrodarsono dan Nakazawa, 1984). Pondasi telapak umumnya 
dibangun di atas tanah pendukung dengan membuat suatu tumpuan yang bentuk serta ukuran (dimensinya) sesuai dengan beban bangunan dan daya dukung tanah pondasi itu. Pondasi itu bersatu dengan bagian utama bangunan dan daya dukung tanah pondasi itu. Pondasi tersebut bersatu dengan bagian utama (tembok penahan tanah, tembok membujur dari kepala jembatan atau kolom dermaga) sehingga merupakan suatu konstruksi yang monolit. Pondasi telapak ini dijabarkan seperti pada Gambar 1. Gambar 2 memperlihatkan pondasi telapak dan tumpuannya.

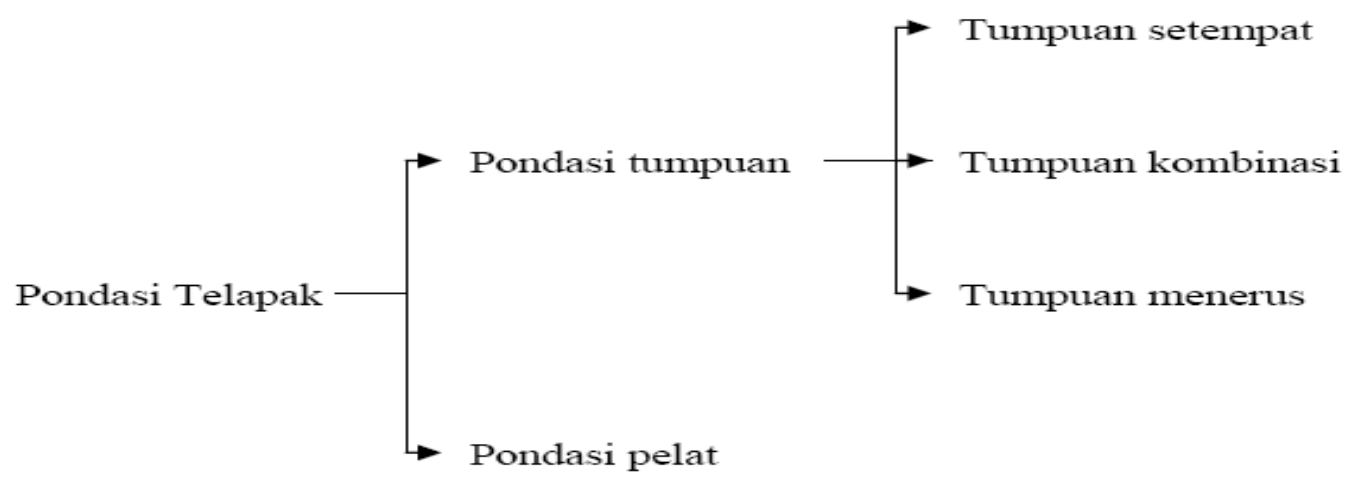

Gambar 1. Bagan Pondasi Telapak.

Alas pondasi telapak terletak pada lapisan tanah pendukung yang mempunyai kualitas cukup baik. Biasanya, selain lapisan batuan dasar atau kerikil, lapisan tanah berpasir (sandy soil) memiliki nilai uji penetrasi tanah $(\mathrm{N})$ yang lebih besar dari 30, dan tanah kohesif memiliki nilai $\mathrm{N}$ yang lebih besar dari 20. Kedua tanah tersebut sebaiknya memiliki ketebalan lapisan yang cukup (lebih dari 1.5 kali lebar dari pondasi), dan dibawahnya tidak terdapat lapisan tanah yang kurang baik kualitasnya (Sosrodarsono dan Nakazawa, 1984).

Mekanisme pendukung pondasi langsung, berdasarkan pada prinsip bahwa beban vertikal dan momen yang bekerja pada pondasi, sebagian besar ditahan oleh daya dukung (bearing capacity) tanah pondasi pada dasar pondasi dan beban mendatar sebagian besar ditahan oleh hambatan geser (sliding resistance) dari dasar pondasi. Jika pondasi tertanam didalam, geseran atau tekanan tanah dimuka pondasi juga ikut menahan beban, tetapi bila ini tertanam dangkal, gaya penahan ini pada umumnya kecil dan tanah di muka pondasi kadangkadang akan mengalami pengikisan dan pengaruh cuaca, sehingga dalam perencanaannya, gaya penahan ini diabaikan. 


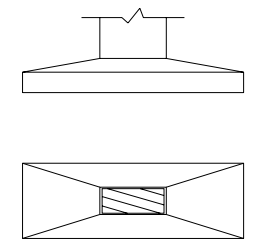

(a) Tum puan tunggal (Independent footing)

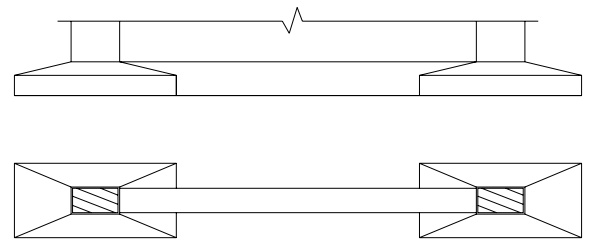

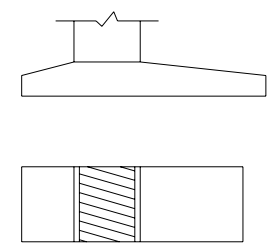

(c) Tum puan m enerus ( W a ll footing)

(b) Tumpuan kombinasi

(Combined footing)
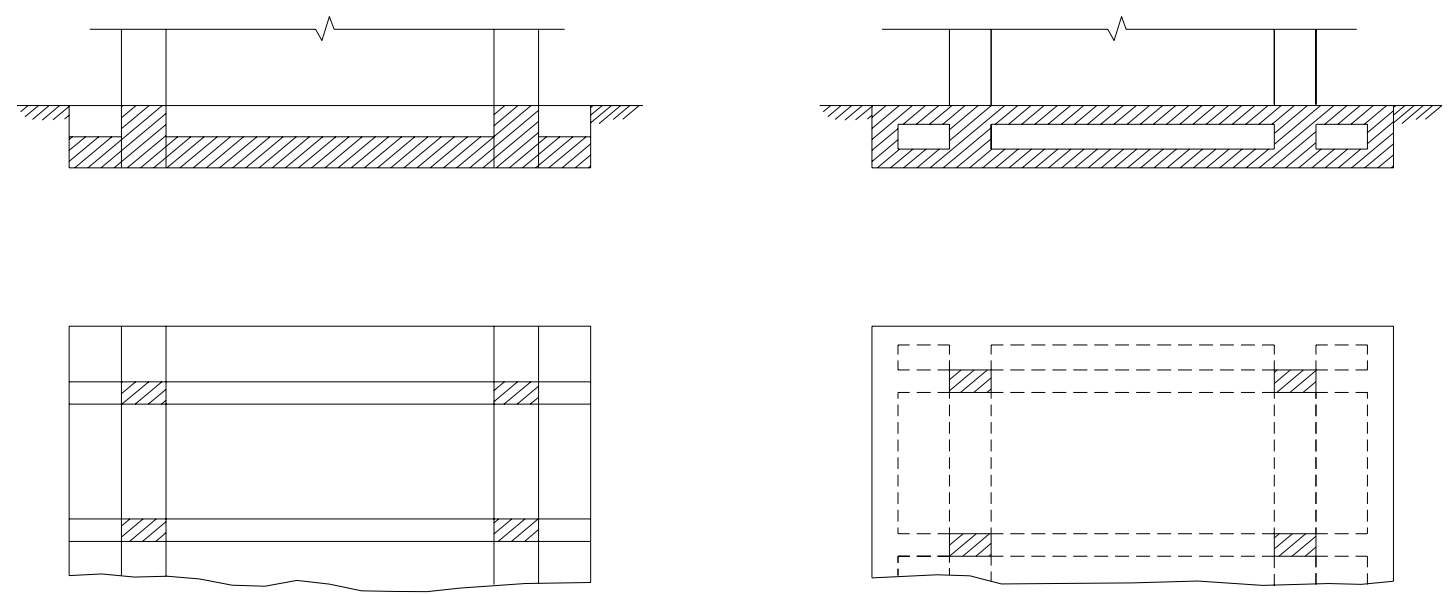

(d) Tumpuan pelat (Raft footing)

Gambar 2. Jenis Pondasi Telapak.

Dalamnya pondasi telapak ditetapkan dengan mempertimbangkan hal-hal sebagai berikut:

1. Kemiringan dasar sungai dan sifat terkikisnya

2. Dalamnya tanah yang menimbulkan perubahan volume

3. Tergantung apa yang tertanam di dalam tanah dan bangunan didekatnya

4. Muka air tanah

5. Derajat dan besarnya ketebalan lapisan tanah pendukung. 
Pondasi telapak harus direncanakan sedemikian rupa sehingga keadaan berikut ini dapat dipenuhi:

1. Struktur secara keseluruhan adalah stabil dalam arah vertikal, arah mendatar, dan terhadap guling

2. Pergeseran bangunan (besarnya penurunan, sudut kemiringan dan pergeseran mendatar), harus lebih kecil dari nilai yang diijinkan dari bangunan bagian atas. Pada pondasi telapak biasa, pergeseran ini tidak dihitung

3. Bagian-bagian pondasi harus memiliki kekuatan yang diperlukan.

\section{MODULUS REAKSI TANAH DASAR}

Modulus reaksi tanah dasar adalah suatu konsep perbandingan antara tekanan tanah dan lendutan yang banyak sekali digunakan di dalam analisis konstruksi. Modulus reaksi tanah dasar tersebut digunakan untuk pondasi telapak kontinu, pondasi rakit dan berbagai jenis tiang pancang. Perbandingan ini dapat dicari dari data pengujian beban pelat. Hasil dari pengujian ini diperoleh data dan hubungan antara tekanan tanah $(q)$ dan penurunan tanah $(\delta$ ) sebagai berikut (Bowles, 1996):

$$
k_{s}=\frac{q}{\delta}
$$

dimana $k_{s}$ adalah modulus reaksi tanah dasar. Tabel 1 memperlihatkan modulus reaksi tanah dasar berdasarkan jenis tanah.

Tabel 1. Modulus reaksi tanah dasar berdasarkan jenis tanah.

\begin{tabular}{|l|c|c|}
\hline \multicolumn{1}{|c|}{ Tanah } & $k_{s}, \mathrm{kcf}$ & $k_{s}, \mathrm{kN} / \mathrm{M}^{3}$ \\
\hline Pasir lepas & $30-100$ & $4800-16000$ \\
\hline Pasir padat sedang & $60-500$ & $9600-80000$ \\
\hline Pasir padat & $400-800$ & $64000-128000$ \\
\hline Pasir padat sedang berlempung & $200-500$ & $32000-80000$ \\
\hline Pasir padat sedang berlanau & $150-300$ & $24000-48000$ \\
\hline Tanah berlempung $200<\mathrm{q}_{\mathrm{u}} \leq 200 \mathrm{kPa}(4 \mathrm{ksf})$ & $75-150$ & $12000-24000$ \\
\hline Tanah berlempung $200<\mathrm{q}_{\mathrm{u}} \leq 400 \mathrm{kPa}$ & $150-300$ & $24000-48000$ \\
\hline Tanah berlempung $200<\mathrm{q}_{\mathrm{u}}>800 \mathrm{kPa}$ & $>300$ & $>4800$ \\
\hline
\end{tabular}




\section{ANALISIS KEKAKUAN PELAT LENTUR}

Pada tulisan ini, pondasi telapak diasumsikan sebagai pelat lentur. Pelat lentur adalah suatu elemen struktur yang datar (tidak melengkung) yang memiliki ukuran tebal jauh lebih kecil dibandingkan dengan dimensi lainnya, dengan arah beban luar yang bekerja tegak lurus dengan bidang strukturnya. Peralihan dari pelat lentur menggunakan teori peralihan kecil (small displacement theory) yang diterapkan pada kontinum. Untuk masalah deformasitegangan, besaran yang perlu untuk ditentukan adalah regangan yang berasal dari suatu peralihan titik. Untuk peralihan yang kecil, regangan $(\varepsilon)$ adalah turunan pertama dari peralihan sehingga akan didapatkan hubungan antara regangan dan lendutan $(w)$ seperti persamaan berikut:

$$
\begin{aligned}
& \varepsilon_{x}=-z \frac{\delta^{2} w}{\delta_{x}^{2}} \\
& \varepsilon_{y}=-z \frac{\delta^{2} w}{\delta_{y}^{2}} \\
& \gamma_{x y}=-2 z \frac{\delta^{2} w}{\delta_{x} \delta_{y}}
\end{aligned}
$$

Rasio regangan lateral $\varepsilon^{\prime}$ terhadap regangan aksial $\varepsilon$ dikenal dengan rasio Poisson sebagai berikut:

$$
v=\frac{\varepsilon^{\prime}}{\varepsilon}
$$

Hukum tegangan-regangan pada suatu bahan homogen isotropic, elastis didasarkan pada hukum Hooke untuk tegangan tiga dimensi. Untuk pelat tipis dengan lendutan kecil, hubungan tersebut disederhanakan menjadi kondisi dua dimensi dengan memberi nilai $\gamma_{x z}=\gamma_{y z}=\varepsilon_{z}=0$ sehingga didapatkan persamaan tegangan dalam fungsi perpindahan seperti dalam persamaan berikut:

$$
\begin{aligned}
& \sigma_{x}=-\frac{E_{z}}{1-v}\left[\frac{\partial^{2} w}{\partial x^{2}}+v \frac{\partial^{2} w}{\partial y^{2}}\right] \\
& \varepsilon_{y}=-\frac{E_{z}}{1-v}\left[\frac{\partial^{2} w}{\partial y^{2}}+v \frac{\partial^{2} w}{\partial x^{2}}\right] \\
& \gamma_{x y}=-\frac{E_{z}}{1-v} \frac{\partial^{2} w}{\partial_{x} \partial_{y}}
\end{aligned}
$$

dimana $E_{z}$ adalah modulus elastisitas.

Akibat tegangan yang terjadi pada pelat, menimbulkan bending momen, bending twisting, serta vertical shear force. Secara umum momen-momen yang terjadi adalah 


$$
\{M\}_{e}=\left\{\begin{array}{c}
-D\left[\frac{\delta^{2} w}{\delta x^{2}}+v \frac{\delta^{2} w}{\delta y^{2}}\right] \\
-D\left[\frac{\delta^{2} w}{\delta y^{2}}+v \frac{\delta^{2} w}{\delta x^{2}}\right] \\
-D(1-v) \frac{\delta^{2} w}{\delta x \delta y}
\end{array}\right\}
$$

dimana kekakuan pelat lentur (flexure rigity of the plate) adalah $D=\frac{E t^{3}}{12\left(1-v^{2}\right)}$.

Persamaan pembentuk (Governing Equation), pelat yang dibebani dengan beban terbagi merata per satuan luas, $\mathrm{p}$ adalah

$$
\frac{\delta^{4} w}{\delta x^{4}}+2 \frac{\delta^{4} w}{\delta x^{2} \delta y^{2}}+\frac{\delta^{4} w}{\delta y^{4}}=-\frac{p k_{s} w}{D}
$$

\section{METODE ELEMEN HINGGA}

Dalam website wikipedia Indonesia dicantumkan sejarah Metode Elemen Hingga (MEH). MEH berawal pada kebutuhan untuk menyelesaikan permasalahan kompleks di bidang Teknik Sipil dan Teknik Aeronautika terutama pada permasalahan elastisitas dan analisa struktur. Perkembangan MEH diawali atas jerih payah Alexander Hrennikoff (1941) dan Richard Courant (1942). Pendekatan yang dilakukan oleh para pioneer ini benar-benar berbeda, namun mereka mempopulerkan satu nilai yang esensial, yaitu: diskretisasi/pembagian jaringan pada sebuah bidang pengaruh (domain) yang menerus menjadi kumpulan sub-domain yang berbeda. Hrennikoff membagi-bagi domain dengan menggunakan analogi kisi-kisi, sedangkan pendekatan yang dilakukan Courant adalah mengubah domain menjadi sub-region dengan bentuk segitiga-segitiga terbatas (finite triangular subregions) sebagai solusi untuk permasalahan Persamaan Differensial Parsial Elips (Elliptic Partial Differential Equation) yang muncul pada permasalahan di bidang torsi pada sebuah silinder. Kontribusi Courant berevolusi, penggambaran hasil awal PDEs dibuat oleh Rayleigh, Ritz dan Galerkin.

Perkembangan MEH secara sungguh-sungguh diawali pada pertengahan sampai dengan akhir dekade 1950an untuk bidang airframe dan analisa struktur dan meraih banyak energi tambahan untuk berkembang pada University of California, Berkeley pada dekade 1960an dibidang teknik sipil. Di tahun 1973, Strang dan Fix melalui tulisannya “An Analysis of The Finite Element Method" mengatakan bahwa MEH menawarkan solusi matematis yang setepat-tepatnya. Perkembangan MEH di mekanika struktur sering didasari pada 
prinsip energi, seperti pada prinsip pekerjaan virtual (eng: virtual work principle) atau prinsip energi potensial total minimum (minimum total potential energy), dimana MEH menyediakan secara keseluruhan intuisi dan basis fisik yang dapat menjadi bahan pertimbangan yang baik bagi para insinyur struktur.

Analisis pelat lentur merupakan struktur dimana analisis struktur yang mudah digunakan melalui metode kekakuan langsung. Metode kekakuan langsung ini memanfaatkan perkalian dan pembagian dengan matriks yang juga dikenal sebagai metode elemen hingga (Hadipratomo, 2005). Konsep dasar yang melandasi metode elemen hingga adalah prinsip diskritisasi atau membagi elemen-elemen sehingga menjadi elemen-elemen lebih kecil sehingga diperoleh solusi dengan elemen hingga. Dalam tulisan ini, pelat lentur dimodelkan sebagai elemen segiempat. Pada tiap simpul elemen segi empat hanya memiliki tiga komponen perpindahan, yaitu : lendutan pada sumbu $z$, rotasi pada sumbu $y$ $\left(\theta_{y}=-\frac{\delta w}{\delta y}\right)$ dan rotasi pada sumbu $x\left(\theta_{x}=-\frac{\delta w}{\delta x}\right)$, rotasi berhubungan dengan kemiringan $\theta$ (slope). Arah positif dari rotasi dapat ditentukan dengan menggunakan aturan tangan kanan (right hand rules) seperti terlihat pada Gambar 3.

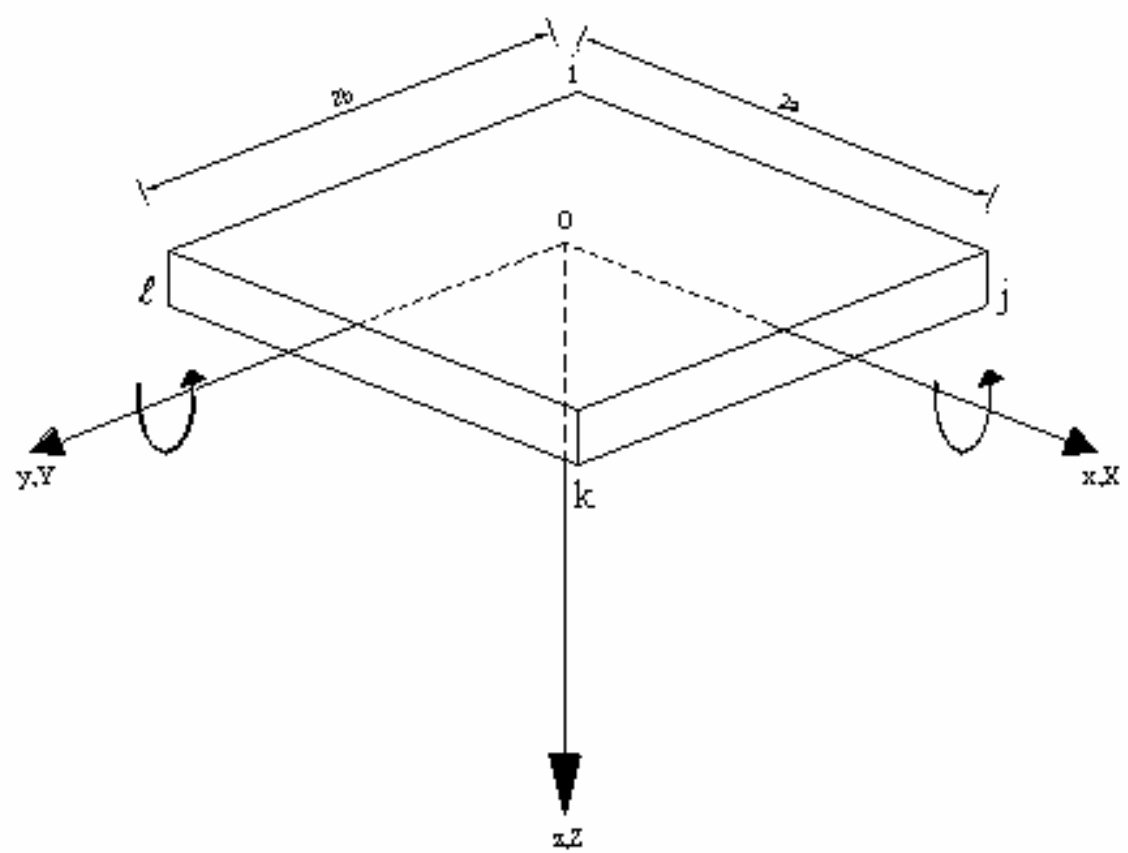

Gambar 3. Elemen Segi Empat. 
Matriks perpindahan simpul (nodal displacement matrix) elemen segi empat dapat dijabarkan sebagai berikut:

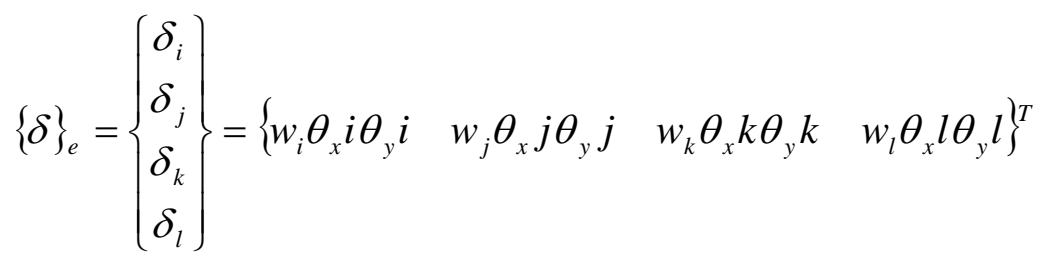

Sedangkan bentuk polinomial dari fungsi perpindahan elemen segi empat dapat dinyatakan dengan:

$$
\begin{aligned}
w_{i}= & \alpha_{1}+\alpha_{2} x_{i}+\alpha_{3} y_{i}+\alpha_{4} x_{i}^{2}+\alpha_{5} x_{i} y_{i}+\alpha_{6} y_{i}^{2}+ \\
& \alpha_{7} x_{i}^{3}+\alpha_{8} x_{i}^{2} y_{i}+\alpha_{9} x_{i} y_{i}^{2}+\alpha_{10} y_{i}^{3}+\alpha_{11} x_{i}^{3} y_{i}+\alpha_{12} x_{i} y_{i}^{3}
\end{aligned}
$$

Matriks perpindahan regangan umum diperoleh sebagai berikut:

$$
\{\varepsilon\}_{e}=[B][A]^{-1}\{\delta\}_{e}
$$

dimana:

$$
[B]=\left[\begin{array}{cccccccccccc}
0 & 0 & 0 & -2 & 0 & 0 & -6 x & -2 y & 0 & 0 & -6 x y & 0 \\
0 & 0 & 0 & 0 & 0 & -2 & 0 & 0 & -2 x & -6 y & 0 & -6 x y \\
0 & 0 & 0 & 0 & -2 & 0 & 0 & -4 x & -4 y & 0 & -6 x^{2} & -6 y^{2}
\end{array}\right]
$$

dan

$$
[A]=\left[\begin{array}{cccccccccccc}
1 & x_{i} & y_{i} & x_{i}^{2} & x_{i} y_{i} & y_{i}^{2} & x_{i}^{3} & x_{i}^{2} y_{i} & x_{i} y_{i}^{2} & y_{i}^{3} & x_{i}^{3} y_{i} & x_{i} y_{i}^{3} \\
0 & -1 & 0 & -2 x_{i} & -y_{i} & 0 & -3 x_{i}^{2} & -2 x_{i} y_{i} & -y_{i}^{2} & 0 & -3 x_{i}^{2} y_{i} & -y_{i}^{3} \\
0 & 0 & 1 & 0 & x_{i} & 2 y_{i} & 0 & x_{i}^{2} & 2 x_{i} y_{i} & 3 y_{i}^{2} & x_{i}^{3} & 3 x_{i} y_{i} \\
1 & x_{j} & y_{j} & x_{j}^{2} & x_{j} y_{j} & y_{j}^{2} & x_{j}^{3} & x_{j}^{2} y_{j} & x_{j} y_{j}^{2} & y_{j}^{3} & x_{j}^{3} y_{j} & x_{j} y_{j}^{3} \\
0 & -1 & 0 & -2 x_{j} & -y_{j} & 0 & -3 x_{j}^{2} & -2 x_{j} y_{j} & -y_{j}^{2} & 0 & -3 x_{j}^{2} y_{j} & -y_{j}^{3} \\
0 & 0 & 1 & 0 & x_{j} & 2 y_{j} & 0 & x_{j}^{2} & 2 x_{j} y_{j} & 3 y_{j}^{2} & x_{j}^{3} & 3 x_{j} y_{j} \\
1 & x_{k} & y_{k} & x_{k}^{2} & x_{k} y_{k} & y_{k}^{2} & x_{k}^{3} & x_{k}^{2} y_{k} & x_{k} y_{k}^{2} & y_{k}^{3} & x_{k}^{3} y_{k} & x_{k} y_{k}^{3} \\
0 & -1 & 0 & -2 x_{k} & -y_{k} & 0 & -3 x_{k}^{2} & -2 x_{k} y_{k} & -y_{k}^{2} & 0 & -3 x_{k}^{2} y_{k} & -y_{k}^{3} \\
0 & 0 & 1 & 0 & x_{k} & 2 y_{k} & 0 & x_{k}^{2} & 2 x_{k} y_{k} & 3 y_{k}^{2} & x_{k}^{3} & 3 x_{k} y_{k} \\
1 & x_{l} & y_{l} & x_{l}^{2} & x_{l} y_{l} & y_{l}^{2} & x_{l}^{3} & x_{l}^{2} y_{l} & x_{l} y_{l}^{2} & y_{l}^{3} & x_{l}^{3} y_{l} & x_{l} y_{l}^{3} \\
0 & -1 & 0 & -2 x_{l} & -y_{l} & 0 & -3 x_{l}^{2} & -2 x_{l} y_{l} & -y_{l}^{2} & 0 & -3 x_{l}^{2} y_{l} & -y_{l}^{3} \\
0 & 0 & 1 & 0 & x_{l i} & 2 y_{l} & 0 & x_{l}^{2} & 2 x_{l} y_{l} & 3 y_{l}^{2} & x_{l}^{3} & 3 x_{l} y_{l}
\end{array}\right]
$$


Menurut Brown (1981), matriks kekakuan elemen $[K]_{e}$ dapat dinyatakan sebagai berikut:

$$
[K]_{e}=[A]^{T}[C][A]^{-1}
$$

(10)

dengan $[C]=\int_{-a-b}^{a} \int^{b}[B]^{T}[D][B] \partial_{x} \partial_{y}$.

Untuk pondasi yang terletak di atas tumpuan elastis, pondasi dianggap didukung oleh beberapa pegas yang saling bebas atau pelenturan setiap pegas tidak terpengaruh oleh pegas-pegas yang ada disebelahnya (Bowles,1996). Jika pegas diasumsikan saling bebas, maka koefisien kekakuannya dapat dijumlahkan secara langsung pada koefisien diagonal matrik global (Desai, 1979). Sehingga matriks kekakuan elemen pondasi pelat dapat dinyatakan sebagai berikut:

$$
\left\lfloor k_{f}\right\rfloor_{e}=[K]_{e}+[k]_{w}
$$

$\operatorname{dimana}[k]_{w}=a b\left[\begin{array}{cccc}{[k]_{s}} & 0 & 0 & 0 \\ 0 & {[k]_{s}} & 0 & 0 \\ 0 & 0 & {[k]_{s}} & 0 \\ 0 & 0 & 0 & {[k]_{s}}\end{array}\right]$ dan $[k]_{s}=\left[\begin{array}{ccc}k_{s} & 0 & 0 \\ 0 & 0 & 0 \\ 0 & 0 & 0\end{array}\right]$.

Gambar 4 merupakan illustrasi pembentukan konstanta pegas.

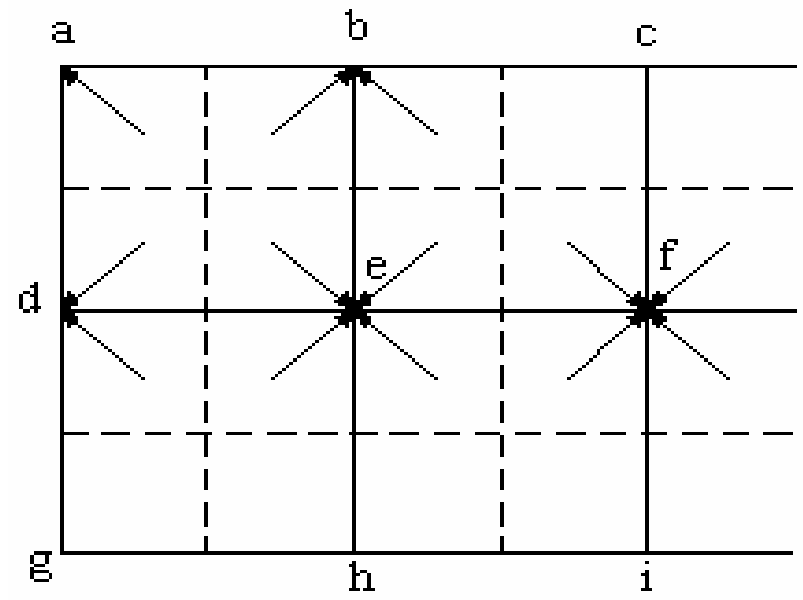




\section{Gambar 4. Pembentukan Konstanta Pegas.}

Ada dua cara penurunan persamaan elemen, yaitu cara energi dan cara residual, tetapi cara energi lebih dikenal, yaitu Prinsip Energi Potensial Minimum (Hadipratomo, 2005). Cara energi ini menyatakan bahwa semua konfigurasi geometrik yang mungkin, yang dapat diasumsikan dan yang benar adalah yang memenuhi kondisi seimbang stabil dan dinyatakan oleh harga minimum energi potensial totalnya (energi regangan dan energi potensial). Sehingga dihasilkan rumus umum:

$$
[K]\{\delta\}=\{F\}
$$

dimana:

$[K]$ matriks kekakuan,

$\{\delta\}$ adalah vektor perpindahan, dan

$\{F\}$ vektor beban.

Vektor beban berasal dari gaya traksi yang timbul akibat interaksi antara pondasi dan medium elastik dan juga beban-beban luar sehingga besarnya gaya reaksi yang timbul dapat diuraikan menjadi

$$
\{F\}=-\left\{F^{0}\right\}+\{P\}
$$

dimana:

$\left\{F^{0}\right\}=$ vektor beban akibat beban elemen,

$\{P\} \quad=$ dan vektor beban yang bekerja pada titik nodal.

Sehingga persamaan umum untuk metode elemen hingga adalah sebagai berikut:

$$
[K]\{\delta\}=-\left\{F^{0}\right\}+\{P\} .
$$

Prosedur umum menggunakan metode elemen hingga untuk desain fondasi telapak adalah sebagai berikut:

1. Menghitung matriks kekakuan elemen (elemen stiffness matrix), $\{k\}_{e}$, kemudian digeneralisasikan menjadi matriks kekakuan global $\{K\}=\sum\{k\}_{e}$

2. Menghitung matriks gaya simpul (nodal force matrix), $\{P\}_{e}$ kemudian digeneralisasikan menjadi matriks gaya global $\{P\}=\sum\{P\}_{e}$ 
3. Menghitung perpindahan titik nodal (nodal displacement) dengan memasukan kondisi batas (boundary conditions), $\{\delta\}=[K]^{-1}\{P\}$.

\section{STUDI KASUS DAN PEMBAHASAN}

Satu contoh pondasi telapak akan dimodelkan sebagai studi kasus. Pemodelan mengambil kasus struktur fiktif seperti pada Gambar 5 dan Gambar 6. Dengan mengasumsikan tanah mempunyai gaya tekan yang diasumsikan sebagai pegas $\left(k_{s}\right)$ terhadap pondasi (Gambar 6).

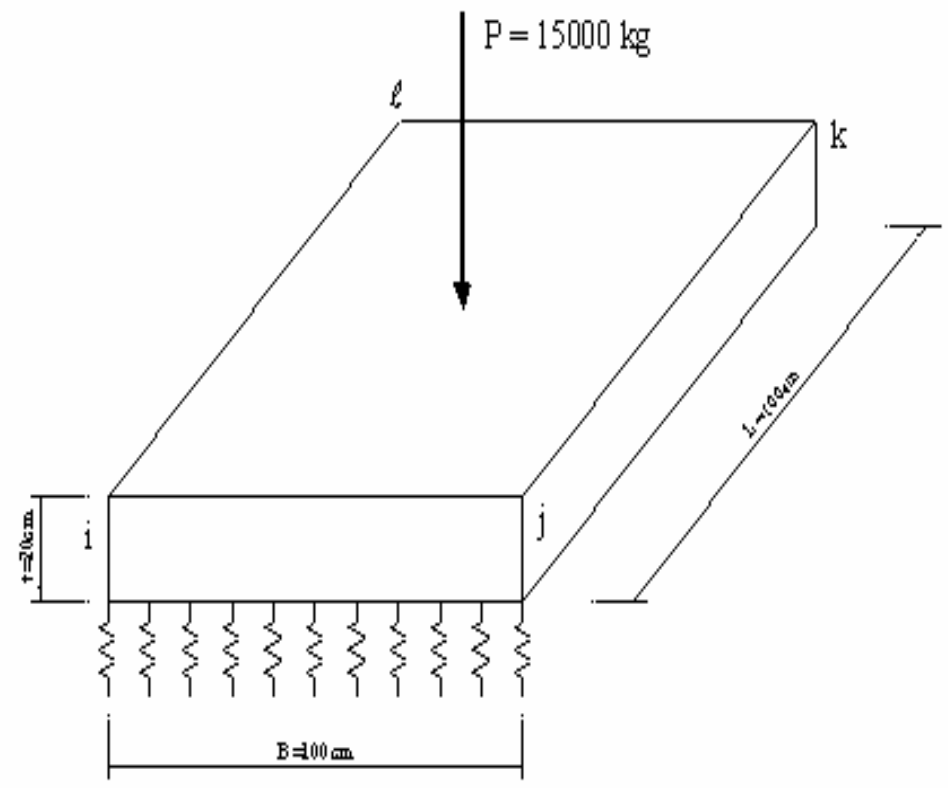

Gambar 5. Model Pondasi Telapak.

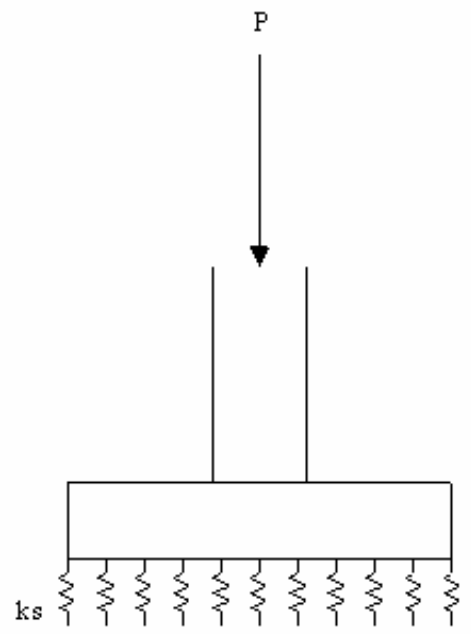

Gambar 6. Gaya Pegas terhadap Pondasi. 
Dalam tulisan ini, nilai $k_{s}$ diasumsikan untuk tanah pasir lepas (sand loose). Untuk jenis tanah seperti ini, adalah $2 \mathrm{~kg} / \mathrm{cm}^{2}$ (Bowles, 1996). Untuk studi kasus ini, Poisson Rasio adalah $v=0,3$, momen Inersia $I=(1 / 12) B t^{3}=66666,667 \mathrm{~cm}^{4}$ dan modulus elastisitas $E=23963330,5 \mathrm{~kg}$ cm dimana $f_{c}^{\prime}=25$ MPa. Rigiditas elemen pelat diperoleh $\lambda L=\sqrt{\frac{k_{s} B L^{4}}{4 E I}}=0,0559<\frac{\pi}{4}$ atau pelat yang digunakan rigid.

Gaya di titik nodal (nodal force) dihitung dengan mengillustrasikan gaya yang bekerja pada balok seperti pada Gambar 7. Hasil perhitungan gaya pada titik nodal dapat dilihat pada Tabel 2.

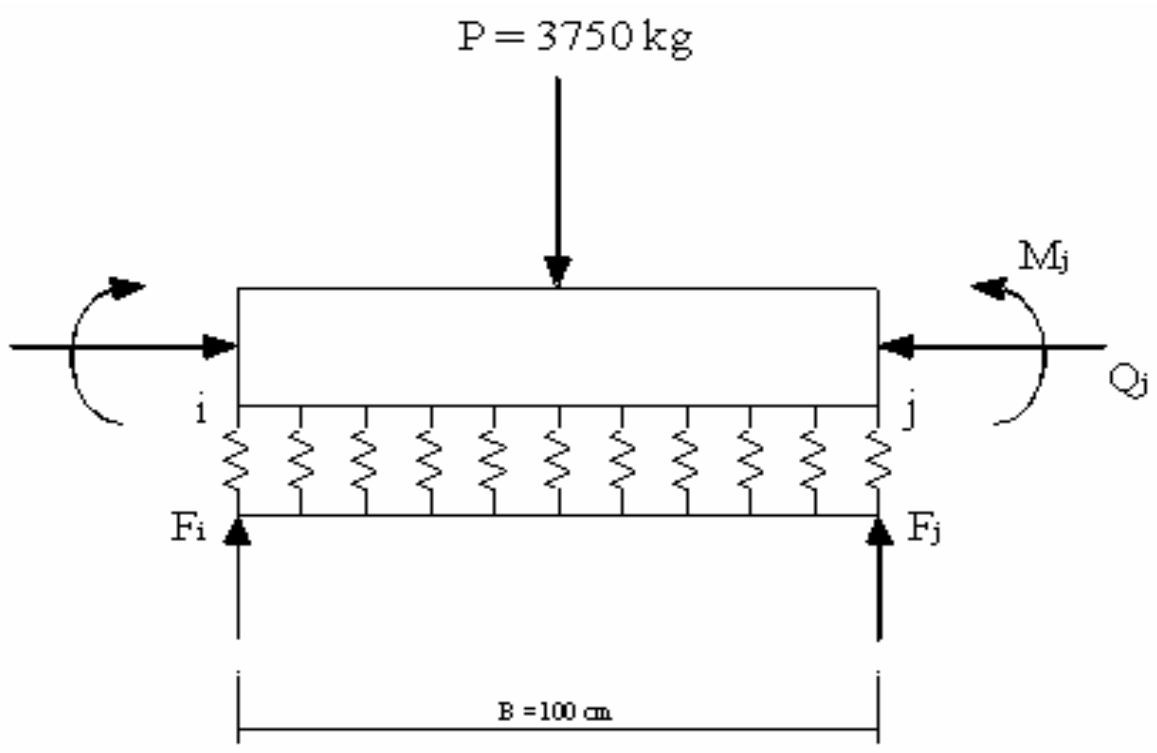

Gambar 7. Gaya yang bekerja pada Balok.

Tabel 2. Gaya pada Titik Nodal.

\begin{tabular}{|c|c|c|c|}
\hline Titik Nodal & F (Kg) & Q (Kg) & M (Kg M) \\
\hline $\mathrm{i}$ & 1875 & 9281.25 & -1875 \\
\hline $\mathrm{j}$ & 1875 & -9281.25 & 1875 \\
\hline $\mathrm{k}$ & 1875 & 9281.25 & -1875 \\
\hline $\mathrm{l}$ & 1875 & -9281.25 & 1875 \\
\hline
\end{tabular}


Lendutan yang terjadi pada elemen pelat tersebut diperoleh dengan cara mengalikan gaya-gaya batang yang terjadi pada titik nodal dengan matrik kekakuan total. Tabel 3 memperlihatkan lendutan yang terjadi pada titik nodal.

Tabel 3. Lendutan di Titik Nodal.

\begin{tabular}{|c|c|}
\hline Titik Nodal & Lendutan $(\mathrm{cm})$ \\
\hline $\mathrm{i}$ & $-2.58910^{-9}$ \\
\hline $\mathrm{j}$ & $-2.78910^{-9}$ \\
\hline $\mathrm{k}$ & $-2.58910^{-9}$ \\
\hline $\mathrm{l}$ & $-2.78910^{-9}$ \\
\hline
\end{tabular}

Sebagai pembanding dilakukan secara numeric dengan menggunakan program SAP 2000 versi 11. Langkah-langkah yang dilakukan sebagai berikut:

1. Pemilihan tipe struktur yang digunakan. Dalam tulisan ini dilakukan perbandingan dengan menggunakan tipe struktur solid.

2. Pengisian data-data yang diperlukan.

3. Pemilihan solid elemen dalam empat mesh area.

4. Pengisian data-data material

5. Pembuatan shell area

6. Pengisian data-data dari shell area dan pengisian tebal pelat

7. Pemasukan load cases

8. Pemilihan kombinasi beban

9. Pengisian data kombinasi beban

10. Pengisian perletakan pegas pada joint

11. Pengisian konstanta pegas dalam arah sumbu Z sebesar $2 \mathrm{~kg} / \mathrm{cm}^{2}$

12. Pemilihan jenis yang akan dianalisis

13. Analisis program

14. Hasil keluaran.

Hasil numerik dengan memanfaatkan software SAP 2000 versi 11, diperoleh lendutan maksimum sebesar $2.78110^{-9} \mathrm{~cm}$. 


\section{KESIMPULAN}

Dengan memodelkan pondasi telapak sebagai pelat lentur, hasil perhitungan dengan metode elemen hingga sederhana diperoleh lendutan maksimum sebesar $-2.78910^{-9} \mathrm{~cm}$. Sebagai pembanding secara numerik dengan menggunakan software SAP 2000 versi 11 diperoleh lendutan maksimum $2.78110^{-9} \mathrm{~cm}$. Persentase perbedaan hasil lendutan yang di dapatkan melalui pemodelan dengan menggunakan metode elemen hingga dan penggunaan software SAP 2000 versi 10, diperoleh $0.28 \%$.

Penelitian lanjut yang dapat diusulkan adalah pemodelan dilakukan dengan memodifikasi beban-beban yang bekerja pada balok. Pemodelan dilakukan dengan mendiskritisasi elemen lebih kecil lagi. Selanjutnya pemodelan tidak terbatas pada pondasi yang berkelakuan rigid saja tetapi pemodelan juga dapat dilakukan pada pondasi dengan kondisi fleksibel.

\section{DAFTAR PUSTAKA}

1. Bowles, J. E (1996), Foundation Analysis and Design, Edisi 5, McGraw-Hill Inc., New York.

2. Brown, D. K. (1984), Introduction to the Finite Element Method using BASIC Programs, Blackie \& Son, Glasgow.

3. Desai, C. S. (1979), Elementary Finite Element Method, Prentice Hall, Inc., Englewood Cliffs, New Jersey.

4. Hadipratomo, W. (2005), Dasar Dasar Metode Elemen Hingga, PT. Danamartha Sejahtera Utama, Bandung.

5. url: http://id.wikipedia.org

6. Sosrodarsono, S. dan Nakazawa, K. (1984), Mekanika Tanah dan Teknik Pondasi, Pradnya Paramita, Jakarta.

[1] Hanny J. Dani adalah dosen tetap Jurusan Teknik Sipil, Universita Kristen Maranatha, Bandung.

[2] Olga Pattipawaej adalah dosen tetap Jurusan Teknik Sipil, Universita Kristen Maranatha, Bandung.

[3] Putra W. Remantan adalah alumni Jurusan Teknik Sipil, Universita Kristen Maranatha, Bandung. 